Article

\title{
Knowledge Management and the Sustainable Development of Social Work
}

\author{
Simon Colnar ${ }^{1, * \mathbb{D}}$, Vlado Dimovski ${ }^{1}$ and David Bogataj ${ }^{1,2}$ \\ 1 School of Economics and Business, University of Ljubljana, 1000 Ljubljana, Slovenia; \\ vlado.dimovski@ef.uni-lj.si (V.D.); david.bogataj@ef.uni-lj.si or david.bogataj@gmail.com (D.B.) \\ 2 Department of Management and Engineering, University of Padua, 35122 Padua, Italy \\ * Correspondence: simon.colnar@ef.uni-lj.si; Tel.: +386-31-787-710
}

Received: 14 October 2019; Accepted: 9 November 2019; Published: 13 November 2019

check for updates

\begin{abstract}
The growing shortage of skilled social workers, accompanied by an ageing population and the increasing number of fragile, elderly individuals that require social services, poses a serious challenge for our society. The magnitude of this problem is seen in the various predictions hypothesizing that, globally, there is likely to be a shortfall of millions of social workers for the successful provision of social services. To make matters worse, there are not enough social work students to fill that void, whereas the existing employee turnover is another serious concern for the social work field. Policy makers in many countries do not yet understand the pattern of growing needs and have no tool to forecast the future increase in educational requirements for creating a pool of adequately skilled social workers. In addition to this, understanding the patterns of workforce entrance and exit for social workers and the dynamics of transition becomes important for national policy and decision makers. In our paper, we build on current research about knowledge management in social work settings to demonstrate that knowledge management can have a positive impact in helping to fulfil the important role of social work in any ageing society. With our research, we contribute to the underdeveloped literature about knowledge management in the public sector and especially in social work settings and to the knowledge-based view of the organization. We present a multiple decrement model of social workers' entrance and transition from social work student and social worker trainee to fully productive social worker, to their exit, whether by changed profession, retirement or death. We argue that the availability of social workers in a national economy depends on the development and operationalization of appropriate policies, where knowledge management can be influential. Our model allows measuring the quality of the national policy system related to the social work profession, something which has not been achieved yet, and shows how knowledge management solutions can positively influence the whole field of social work. We apply an objective measuring tool, grounded in an already developed actuarial-mathematical method. Our case relies on the collection and analysis of relevant data found in publicly available statistical reports for Slovenia. Existing data enables us to provide assumptions on how to better forecast the transition of social workers.
\end{abstract}

Keywords: knowledge management; social work; sustainable development of social work; social work centers; multiple decrement model

\section{Introduction}

Social sustainability can be defined as a process for creating sustainable, successful environments that promote wellbeing, by understanding what people need from the places where they live and work [1]. Moreover, social sustainability combines design of the physical realm with design of the social world, namely infrastructure to support social and cultural life, social amenities, systems for citizen 
engagement and space for people and places to evolve [2]. The social dimension of sustainability has gained rather inadequate attention and recognition in previous studies, considering that this aspect is typically difficult to define and operationalize [3,4]. Consequently, most of the previous initiatives have primarily focused on the economic and environmental aspects of sustainable development, while overlooking the social dimension of sustainability $[5,6]$. Social sustainability, however, is integral to the quality of a human system, as it fosters lasting conditions for human wellbeing, particularly for the most vulnerable individuals or groups [3,7], including the elderly. Mutual development of knowledge management and social sustainability could potentially enhance the overall performance levels of social work organizations. Moreover, if knowledge management initiatives are properly implemented, they may positively influence the sustainability of the entire social system in any ageing society. Additionally, we argue that the sustainability of any social system is not only a problem of public finances but that it is also about ensuring an adequate number of skilled social workers. Currently, we are dealing with a decrease in the availability of social workers, while at the same time, the requirement of social services for the elderly is constantly growing. Therefore, we must determine whether we have enough social workers available for the sustainable provision of wellbeing for service users in social work. Such initiatives may also positively influence the sustainability of public finances, following possible efficiency improvements [8].

Knowledge and the way it is managed has been with humankind since the beginning of time [9]. Nowadays, in the knowledge economy, an organization's ability to manage knowledge effectively is increasingly more crucial [10]. Similarly, authors [11] believe that knowledge management can equip employees with real time information so that they can react appropriately and make decisions that will allow them to successfully fulfil organizational goals. Previous research already established four basic knowledge management process stages, namely creating knowledge, storing and retrieving knowledge, transferring knowledge and implementing knowledge [12]. Knowledge creation typically involves tapping the tacit and, in most cases, highly subjective, insights, informal skills and practice (or know-how) of individual employees in ways that an organization can act on [13]. For organizations, it is also important to appropriately arrange and store their knowledge, as it enables them quicker and easier access and distribution of knowledge within the organization [14]. Furthermore, knowledge transfer is another integral part of knowledge management, as it enables organizations to absorb and appropriately use knowledge of paramount importance for their functioning and follows the key goal of turning knowledge into organizational assets and resources [15]. Among the resources examined, an organization's knowledge or intellectual assets are generally considered the most critical for its long-term successful functioning [16]. Knowledge implementation is the final stage of the knowledge management process that creates real value for the organization by making knowledge active and relevant [17]. In addition, management support can be perceived as the degree to which management understands the importance of knowledge management and the extent to which it participates in its implementation and activities [18]. Additionally, the support and active participation of managers could significantly influence the positive outcomes of knowledge management in organizations [19]. From the perspective of organizations, it is particularly important to determine the effectiveness of knowledge management and its overall contribution to organizational performance. As knowledge is an intangible strategic asset of an organization, its measurement possesses a serious challenge [20]. However, [21] argues that it is possible to measure the effectiveness of knowledge management with changes in soft measures such as enhanced communication, enhanced collaboration, enhanced learning and enhanced performance. Moreover, improvements in the aforementioned aspects could result also in improved service quality.

Knowledge management has captured the attention of researchers in the knowledge-based economy [22], with interest in this academic and practice-oriented discipline witnessing a significant rise in recent years [23-25]. There is also a need nowadays to gain additional insight into how knowledge management is evolving within the context of public sector organizations [26], including social work organizations. Researchers have argued that the adaptation and implementation of 
knowledge management practices can be beneficial [27] in any type of organization, whether private or public [28], and can play an important role [29] in improving the wellbeing of services users and the quality of services and programs offered to them [30,31]. However, few studies focus on knowledge management initiatives in the public sector, especially in comparison to the private sector [32,33]. The scattered and limited understanding of knowledge management in the context of the public sector $[32,34]$ is a major challenge for organizations, as knowledge becomes more and more a critical resource for their functioning [35]. However, it is also important to acknowledge that dominant discussions related to knowledge management in general are not adapted to fit the context of the public sector and social work [36]. Therefore, we must consider that public sector organizations function in a unique context that differs significantly from the private sector. Simply implementing private sector knowledge management tools and models that worked well in that environment might prove to be counterproductive in the context of the public sector [26], and more so in social work. Another specific related to social work is that in general employees are more reluctant to embrace "quantocentric" cultures and approaches [37]. Moreover, there is growing discontent among social work professionals as the levels of formalization of social work practice increase [38]. Consequently, what is needed for the successful implementation of knowledge management in the public sector is the development of a research area that has been largely unexplored [27]. Public sector organizations and their employees must also acknowledge these challenges when discussing knowledge management initiatives, as the need and significance of knowledge management for the public sector are now overwhelming [39]. Moreover, researchers [39] believe that the only question that remains for public organizations is not if but how can they benefit the most from knowledge management initiatives.

Social work is considered as particularly important because it closely follows its mission to enhance human wellbeing and help meet the basic needs of all people, with particular attention to the needs and empowerment of people who are vulnerable, oppressed, and living in poverty [40]. Its commitment to support and help people makes social work different from many other professions [41], and authors [40] believe that it has an important role to play in any ageing society. In our research, we opted to focus on Slovenian social work centers that are and have been the basic institutions, which through measures and services for social security, cover the predominant part of social protection on the national level. Their founder is the state, and the central role as the coordinators of social protection and welfare services devolves upon them [42]. Currently, there are approximately 1250 employees in Slovenian social work centers [43]. Slovenia is similar to other countries experiencing a shortage of skilled social workers [44]. Due to the existing shortage, guaranteeing the supply of an adequate workforce that is engaged in practice and for educating future social workers is one of the core challenges for all societies. Such shortages should also raise an important concern for national policy and decision makers. We argue that similar to the case of nursing staff shortages [45], specific models for workforce forecasting with regard to social workers will be gaining in importance and recognition. Effective forecasting models help managers and policy and decision makers to predict possible shortages or excesses of workforce and its consequences for organizational activities such as planning of activities and annual budgets [45]. Actual data from 2015 show that the European Union had the second highest old-age dependency ratio (29.2\%) after Japan (42.7\%). The old-age dependency ratio is expected to rise in the European Union by 25 percentage points by 2070, reaching 54.2\% [46]. As such, this ratio is going to have a significant impact on the future functioning of our ageing society. Population ageing accompanied by the decrease in births and increasing life expectancy over the last century has already had a strong influence on the changes in the global age structure [47]. The number of people over 60 will grow from 901 million in 2015 to 1.4 billion in 2030 [48]. In addition to this, for example in Slovenia, there will be $31.5 \%$ of persons aged 65 years or more in 2060, in comparison to the $20.4 \%$ in 2020 [49]. As the population ages and lives longer, the need for social services increases. Long-term care will become even more important and will require an additional number of skilled social workers [50].

Therefore, we believe it is of crucial importance to develop a better understanding of knowledge management in general in the particular context of the public sector, including social work organizations. 
Moreover, appropriately implementing knowledge management in practice through the more systematic and effective capture, dissemination, transfer and implementation of knowledge in the context of the public sector, including social work services, is perceived as important due to its impact on influencing public policies [51], improving the wellbeing of social services users and the quality of services and programs [30,31], as well as ensuring an adequate number of skilled social workers. Knowledge management in the context of social work is intended to add value to services by increasing wellbeing, societal effectiveness and general welfare [52,53], and is not solely focused on generating profit and competitive advantages, as is typically the case in the private sector [34]. Moreover, due to various objective barriers such as time and energy, many of the social work knowledge nowadays remains hidden in organizations [54]. While discussing knowledge management in the context of social work can be very important, it can also be explained with the fact that often the ability of such organizations to achieve their goals is in close correlation to the experience and skills of their employee [55]. Moreover, reference [56] argues that access to knowledge, and the skills of employees to use knowledge effectively, importantly influences realizing the benefits to individuals and their lives, which is something that social organizations primarily aim to achieve. Therefore, a knowledgeable, highly skilled and competent workforce is the integral component when discussing transformation of outcomes for services users. Especially the role of knowledge, which empowers employees with resources, skills and the ability to seek and share knowledge, as well as implement it in practice as an integral part of their everyday tasks and learning activities. Nowadays, social work organizations can already be labelled as knowledge intensive organizations, as they are reliant on the knowledge of their employees so that they can provide services, rather than relying on their physical capital [57]. Therefore, in our paper, we consider knowledge management as the ability of social workers to be able to better utilize their existing resources for achieving the wellbeing of service users. Knowledge management can additionally positively influence the job satisfaction of individual employees [58], which raises motivation levels of individuals [59] and mitigates their turnover intentions [60]. As such, we argue that it can foster the sustainable development of the social dimension of sustainability and social work, which is of paramount importance in ageing societies. However, it is also important to acknowledge the existing conditions of social work such as high staff turnover, lack of training and education, and lack of preparation for additional tasks as they can all hamper the successful functioning of social work organizations and proper implementation of knowledge management [61].

Despite knowledge management being of paramount importance, though, the academic research of knowledge management in the public sector is still in its nascent stage [39]. Knowledge and understanding about knowledge management in social work in particular is scarce $[62,63]$. Furthermore, authors [26] argue that the public sector research on knowledge management is clearly fragmented, typically being dominated by unrelated research in the education and research sectors. This highlights an important challenge related to knowledge management research in the public sector, as it provokes researchers to tackle the topic also in other public sector fields and organizations such as social work centers in our research. Additionally, authors [26] posit, that researchers have so far neglected fields that would possibly have the largest impact on the society as a whole, including the sustainable development of social work.

In addition to this, we believe that examining the relationship between knowledge management and the availability of social workers is important, given that this aspect has been neglected in previous studies. In our paper, we present a multiple decrement model of social workers' entrance and transition from social work student and social worker trainee to fully productive social worker, to their exit, whether by changed profession, retirement or death. We are also following the proposition advanced by [26], of continuing the evolution of public sector knowledge management and tackling existing research needs to provide insight to other practitioners, academics and national policy and decision makers. We conduct our initial quantitative analysis about existing knowledge management practices on data of 98 employees in Slovenian social work centers, obtained through online questionnaires and in-person contact. We include social work centers as according to [43], a modern, professional and 
effective system of social care is needed in order to appropriately address the increasingly demanding and complex needs of services users. Moreover, as indicated by [64] the successful resolution of the needs of services users nowadays requires broader knowledge from different fields and [65] argues that the role of knowledge and knowledge management in the whole process can be particularly important. In addition, authors [55] believe that knowledge management is continuously spreading beyond its original private sector focus and is creating links to other disciplines such as social work that were hard to imagine at the beginning of knowledge management. Moreover, as indicated by [66] in the context of Slovenia public sector managers and employees lack sufficient skills and knowledge in (knowledge) management topics. As social work is an important part of the public sector, this gap in knowledge is also present social work. We therefore argue that the potential of knowledge management in social work is high as it is a field that is nowadays underdeveloped and underutilized in practice in social work. We first estimate the extent and effectiveness of existing knowledge management practices using descriptive statistics in the SPSS software (version 24.0). To test the reliability of our measurement instruments, we analyze the Cronbach's $\alpha$ of all nine constructs. Later, the impact of knowledge management on the sustainable development of social work is analyzed using a multiple decrement model. In determining special cases of a multistate transition model, we follow the examples of [67-69].

The primary goal of our study is to contribute to the underdeveloped literature about knowledge management in the public sector [26] and especially in social work settings [62,63]. The intent of our paper is to partially fill this gap with a theoretical analysis followed by an empirical examination that links knowledge management and social work by considering the positive effects of knowledge management on the availability of skilled social workers. In this way, we would respond to certain shortfalls in the existing research and contribute to the theoretical advancement of the field [39]. In addition to this, our paper also continues with the tradition of [70], who started exploring how professional caregivers can organize in more effective ways, in particular how can they share (or transfer) and implement knowledge in order to deliver high-quality services and ensure wellbeing for their users. This new focus on knowledge management in social work setting is extremely promising as an area of exploration in the context of the broader public sector [71]. By particularly focusing on social work organizations, our paper extends previous studies on knowledge management in the public sector as they were typically exploring the education and research sectors [26]. Additionally, in line with the knowledge-based view of the organization [72-74], our study recognizes the important role of knowledge in social work centers as potentially the primary source influencing their functioning. A paradigm shift towards a knowledge-based view of the organization is also suggested by some social work researchers $[75,76]$. We also aim to contribute the previously neglected aspect of sustainable development, the social dimension of sustainability [5,6]. Empirically, our research will provide support to social work centers in their evaluation of existing knowledge management practice and will potentially emphasize the importance of implementing such initiatives in the future. Moreover, the results of our study are intended to promote the necessity of sustainable development of social work among policy and decision makers who matter, at the national level. Our quantitative approach provides a methodological foundation, as the majority of previous works exploring managerial topics in social work organizations have relied on qualitative approaches, being mainly case studies and interviews [17]. As such, our quantitative paper follows the example of [77] in promoting methodological diversity in the social work field, considering that the scope of social work research is indeed broad and multidisciplinary.

\section{Materials and Methods}

Primary data from respondents were collected from May 2018 to January 2019. We opted for an adapted online and in-person questionnaire, which was filled out by social work managers and social work employees in Slovenian social work centers with approximately 1250 employees [43]. Our sample frame consists of e-mail contacts of employed individuals available to the Social Chamber of Slovenia and the subsequent personal contacts developed with individual respondents. 
We established numerous personal relationships with managers and employees in social work centers and sent several reminders to respondents to fill out our questionnaire in order to tackle the issue of non-response bias. Researchers [78,79] define that common method bias could potentially result from artefactual covariance between independent and dependent variables, where one respondent answers all measures, similar to single source data collected through questionnaires, as is also the case in our study. To counteract the negative aspects of common method bias, we enabled the respondents to remain anonymous at all times and encouraged them to provide answers as honestly as possible. 98 respondents completed the whole questionnaire. We edited and analyzed the data in the SPSS software (version 24.0). The response rate in our study is 7.9\%. The largest proportion of respondents work in an organization with 26 to 50 employees (33.3\%) and in an organization with 50 or more employees (33.3\%). More than two thirds of respondents $(71.3 \%$ ) are aged from 30 to 49 years. $80.2 \%$ are women, which is consistent with the observation of authors [80], that social work is predominantly a female profession. $64.5 \%$ of respondents have successfully acquired level 7 of education as explained in the Decree on the introduction and use of the classification system of education and training in Slovenia. $78.7 \%$ have been employed in their present organizations for at least 6 years.

For individual constructs, which measured the extent and effectiveness of knowledge management in social work centers, we select measurement instruments that are in the scientific environment: (1) well established: developed and/or used by some of the key authors of the examined topics; (2) frequently used: scientific papers that consider the development of measurement instruments are often cited; (3) up to date: the relevant measurement instruments are also used in the latest research. We measure management responsibility with 7 items. Statements intended to measure the opinion of respondents regarding management responsibility and were focused on whether an organization has a specific manager dedicated to knowledge management, the level of management support for knowledge management and the existing incentive structure. We measure knowledge creation with 2 items that were exploring the creation of new ideas in a social work center and its subsequent critical evaluation. Similarly, we measure knowledge storage and retrieval with 2 items. We examine how knowledge is stored and retrieved with a particular focus on whether social work centers have standard procedures and databases. 5 items were used to measure knowledge transfer in organizations with emphasis on whether they have readily available knowledge for transfer and gaining insight about individual employees that possess specific knowledge. To measure knowledge implementation, we used 6 items in order to analyze how knowledge implementation impacts organizational performance and to gain an understanding whether the newly gained knowledge is actually used in their daily practice. We measure enhanced collaboration through 3 items. The items were intended to focus on improved collaboration and improved team work. We utilize 2 items to measure enhanced communication. The items were designed to gain insight into the existing communication structure. Similarly, we measure enhanced learning with 7 items. We examine how this influences the ability to improve innovativeness, learning, competences and experience. To measure enhanced performance, we used 4 items in order to analyze how it impacts improved processes, enables better decision making and contributes towards an overall better functioning organization in a very general manner.

The application of life table techniques to the study of labor force status and mobility was first suggested by [81]. Such a life table can be constructed for a fixed group of people who share a membership-defining event (the cohort) [82], such as members of a defined profession, in our case social workers. Similarly, multistate work-life expectancy models have been used in studies by several authors [82-87], especially focusing on occupational health or pension models. Authors [82] argue that work-life and related expectancies are conceptually the same as health expectancies, both being an expected occupation time, with the difference being that the former occur in the context of labor force activity rather than in health statistics. Therefore, as our focus is on examining the availability of social workers and their entrance into and exit from the profession, we rely on using multiple decrement models, as explained below. 
Multiple decrement models that represent a special case of multistate transition models were already developed by [67-69]. For successful forecasting of employment productivity states into which social workers can be organized, we will further develop the model for forecasting the entrance and exit to and from the social work profession. The basic model allows us to forecast the number of social workers entering and exiting the profession in each age cohort and derives the probabilities of transition at various ages on the national level, based on a demographic multiple decrement model $[88,89]$. The model will enable long term projections of available social workers in different states of productivity. The model will also enable an understanding of the patterns of social workers that enter and exit the workforce and how different policies can influence the dynamics of the existing workforce of social workers at different age cohorts. The increase in number of social workers due to novel policy tools and potential effects of knowledge management has not been included in the model yet. Social workers can move among various states such as social work student, social worker trainee, fully productive social worker, to exit by changing profession, by retirement or in the event of death (see Figure 1). Multiple decrement models are currently being used in disability insurance [88]. In our research, they will be extended as a tool for human resource management and for forecasting the entrance and exit of social workers. In multiple decrement models that have $m$ different states for social workers, there are $m+1$ states for transition from one state to another.

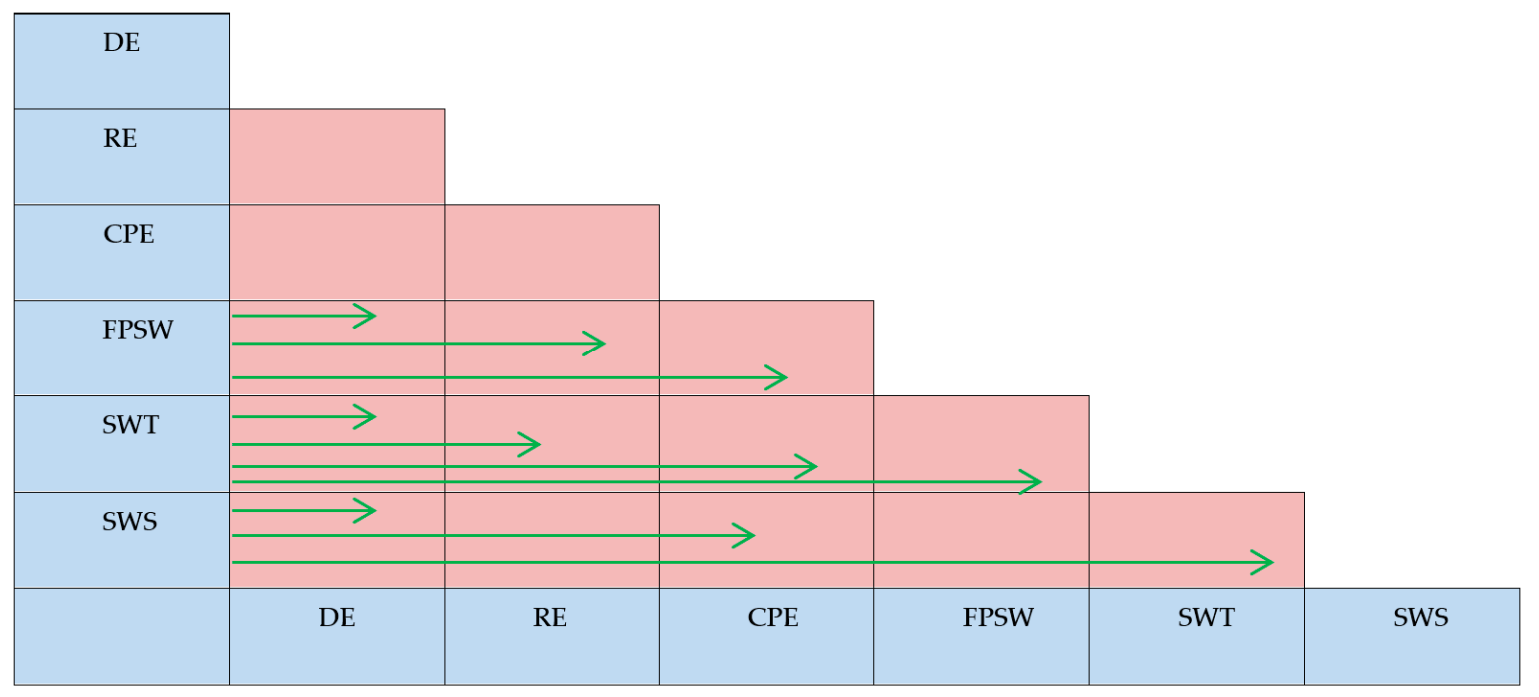

Figure 1. Transitions to and from employment for social workers. Legend: SWS-social work student; SWT_-social worker trainee; FPSW—fully productive social worker; CPE—changed profession exit; RE-retirement exit; DE—death exit; significant transitions for policy and decision makers are marked with green arrows.

We denote the initial state where the individual is a social work student as state 0 and transition, which models social workers in state of type $j$, by the line of the graph from this child node to the state (node) $j, j=1,2, \ldots, m$. The model should describe the probabilities of transition from state 0 to state $\mathrm{j} \in \mathrm{SW}$ (where SW is a set of different types of social workers) or, in general, from the child node to node $j$ at various time points. All paths to $j$ determine the dynamics of human resource management (state of type j) or different types of social worker exit (by changed profession, retirement or death). In a multiple decrement setup, transition between any two states, from $i$ to $j, i>j=1,2, \ldots, m$ is not possible (directed graph). Let us consider a social worker aged $\mathrm{x}$ denoted by $(\mathrm{x})$. We denote the future work period of the social work that they will do in a current state (type of employment) $i \in S W$ by $\mathrm{T}_{\mathrm{i}}(\mathrm{x})$. Therefore, $\mathrm{x}+\mathrm{Ti}(\mathrm{x})$ will be the age when the social worker exits the current state $\mathrm{i}$ and enters $\mathrm{a}$ new state, $j \in S W$. The future work period in the category of type $i, T_{i}(x)$, is a random variable with probability distribution function.

$$
\operatorname{Gi}(\mathrm{t})=\operatorname{Pr}(\mathrm{Ti} \leq \mathrm{t}), \mathrm{t} \geq 0
$$


The function $\mathrm{G}_{\mathrm{i}}(\mathrm{t})$ represents the probability that the social worker will exit the profession due to different reasons, such as death, retirement or a change in profession (state type of $\mathrm{j}$ ) within $\mathrm{t}$ years, for any fixed $t$. We assume that $G_{i}(t)$, the probability distribution of $T_{i}$ is known. We also assume that $G_{i}(t)$ is continuous and has probability density $g_{i}(t)=G_{i}{ }^{\prime}(t)$. Data for $G_{i}(t)$ should be available from the national statistics office. As such, we describe:

$$
\text { gi }(\mathrm{t}) \mathrm{dt}=\operatorname{Pr}\left(\mathrm{t}<\mathrm{T}_{\mathrm{i}}<\mathrm{t}+\mathrm{dt}, \mathrm{i} \in \mathrm{SW}\right)
$$

where Equation (2) describes the probability that the social worker will transfer from state of type I in the infinitesimal time interval from $t$ to $t+d t$. Therefore, the probability that a social worker $x$ years old in state of employment $i$ will transfer into a state of employment $j$ within $t$ years is denoted by the $t$ $\mathrm{q}_{\mathrm{x}}(\mathrm{i}, \mathrm{j})$. Consequently, we have a known relationship:

$$
\begin{gathered}
\text { t } q_{x}(i, j)=G(i, j: t) \\
t p_{x}(i)=1-G(i, j: t)
\end{gathered}
$$

which denotes the probability that a x years old social worker will remain in his or her current state at least for $t$ years.

The graph starts at the initial state $\mathrm{i}=\mathrm{SWS}$ (social work student). We can observe all possible paths from SWS through some of the identified child nodes $j \in S W$, which enable different exits from states. Namely such exits from the social workers' workforce include the possibility of employment in other professions, retirement or death.

Forecasting future distribution of social workers $\mathrm{S}$ according to the type of state based on current distribution of social workers among different types of states and matrix of transitions among different types of states for social workers $x$ years old in multiple decrement model $(i \rightarrow j ; i \in S W, j \in S W$ ) will be described by transition equations:

$$
\begin{gathered}
S_{x+1, \tau+1}=S_{x, \tau} P_{x, \tau}= \\
{\left[S_{x}^{(0)} S_{x}^{(1)} S_{x}^{(2)} S_{x}^{(3)} S_{x}^{(4)} S_{x}^{(5)}\right]_{t}\left[\begin{array}{cccccc}
p_{x}^{(0)} & q_{x}^{(0,1)} & q_{x}^{(0,2)} & q_{x}^{(0,3)} & q_{x}^{(0,4)} & q_{x}^{(0,5)} \\
0 & p_{x}^{(1)} & q_{x}^{(1,2)} & q_{x}^{(1,3)} & q_{x}^{(1,4)} & q_{x}^{(1,5)} \\
0 & 0 & p_{x}^{(2)} & q_{x}^{(2,3)} & q_{x}^{(2,4)} & q_{x}^{(2,5)} \\
0 & 0 & 0 & p_{x}^{(3)} & q_{x}^{(3,4)} & q_{x}^{(3,5)} \\
0 & 0 & 0 & 0 & p_{x}^{(4)} & q_{x}^{(4,5)}
\end{array}\right]_{t}} \\
=\left[S_{x+1}^{(0)} S_{x+1}^{(1)} S_{x+1}^{(2)} S_{x+1}^{(3)} S_{x+1}^{(4)} S_{x+1}^{(5)}\right]_{t+1}
\end{gathered}
$$

Appropriately implementing knowledge management activities can influence the quality of human resource management and thus also the intensity of transitions. The details of the transitions will be modelled as a directed graph. By observing all possible paths from the initial state through transition types of states in different states (transition nodes in the graph), based on national demographic statistics, one can calculate the projected labor supply of different categories. Knowledge management solutions will be needed for such transitions that also remain subjects of further research. Our model will be further developed in the future, based on the theoretical foundations of [68].

\section{Empirical Results}

\subsection{Extent and Effectiveness of Knowledge Management in Social Work Centers}

Table 1 presents descriptive statistics for all nine constructs analyzed in our paper that are related to the extent and effectiveness of knowledge management in social work centers.

From the results in Table 1, we can see a moderate mean value for the construct of knowledge transfer (3.51). The mean values for the other four constructs that measure the extent of knowledge 
management in social work centers show low or at best moderate values. The mean values are: management responsibility (2.77), knowledge implementation (2.81), knowledge creation (2.87), knowledge storage and retrieval (2.94). Our part of the research that focused on the effectiveness of knowledge management in social work centers had a necessary condition. Respondents had to declare that their respective organization formally or informally engages in knowledge management activities. Consequently, this might influence the potential favorable opinions towards the effectiveness of their existing knowledge management efforts. Nevertheless, we found only moderate mean values for all four measured constructs that measure the effectiveness of knowledge management in social work centers. The mean values are as follows: enhanced communication (3.43), enhanced performance (3.50), enhanced collaboration (3.60), improved learning (3.63). The mean values indicate that the activity levels of knowledge management in the practice of social work centers are at best moderate. Similarly, the mean values also suggest that knowledge management is in practice only moderately effective.

Table 1. Mean values, standard deviation and Cronbach's $\alpha$ for all measured constructs.

\begin{tabular}{cccc}
\hline Variable & Mean & SD & Cronbach's $\alpha$ \\
\hline 1. Management responsibility & 2.77 & 0.97 & 0.90 \\
2. Knowledge creation & 2.87 & 1.10 & 0.84 \\
3. Knowledge storage and retrieval & 2.94 & 1.15 & 0.87 \\
4. Knowledge transfer & 3.51 & 0.86 & 0.82 \\
5. Knowledge implementation & 2.81 & 0.96 & 0.91 \\
6. Enhanced collaboration & 3.63 & 0.55 & 0.90 \\
7. Enhanced communication & 3.59 & 0.47 & 0.62 \\
8. Enhanced learning & 3.58 & 0.61 & 0.86 \\
9. Enhanced performance & 3.42 & 0.45 & 0.42 \\
\hline
\end{tabular}

\subsection{Case Study of Slovenian Female Social Workers}

As mentioned in previous paragraphs, appropriately implementing knowledge management can influence the intensity of transitions between different states. Moreover, it can positively impact the perceived job satisfaction among individuals [58], that consequently improves the motivation of individuals [59] and reduces their turnover intentions [60]. Therefore, we present the hypothesized impact of knowledge management on the transitions using a sample of Slovenian social workers. As the population of social workers employed in social work centers is too small, we additionally focus on the whole sector of social work. Our assumption is that the transitions will be similar in the social work sector as a whole and in individual social work centers. The number of employees in social work in Slovenia in 2017 was 19,373 [90], of which 1250 are employed in social work centers [43]. We present the age structure in 5-year age cohorts in Table 2:

Table 2. Employees in social work 2017.

\begin{tabular}{ccccccccccccc}
\hline Ages & Total & $\mathbf{1 5 - 1 9}$ & $\mathbf{2 0 - 2 4}$ & $\mathbf{2 5 - 2 9}$ & $\mathbf{3 0 - 3 4}$ & $\mathbf{3 5 - 3 9}$ & $\mathbf{4 0 - 4 4}$ & $\mathbf{4 5 - 4 9}$ & $\mathbf{5 0 - 5 4}$ & $\mathbf{5 5 - 5 9}$ & $\mathbf{6 0 - 6 4}$ & $\mathbf{6 5 +}$ \\
\hline Social workers & 19,373 & 107 & 937 & 1596 & 2157 & 2443 & 2826 & 3050 & 3447 & 2298 & 492 & 20 \\
\hline \multicolumn{10}{c}{ Data source: [90]. }
\end{tabular}

The transition matrix could be written based on demographic data and employment tables for different occupation groups for the year 2017, which were collected at the state level by [90]. As social work is predominantly a female dominated profession [80], we focused on female social workers aged 45 years old. The structure of female social workers aged 45 years old who are distinguished due to their different category is represented by the vector $S_{x}$, being the sum of net transitions of cohort:

$$
S_{45}^{2017}=\left[S_{45}^{(0)} S_{45}^{(1)} S_{45}^{(2)} S_{45}^{(3)} S_{45}^{(4)} S_{45}^{(5)}\right]_{2017}=\left[\begin{array}{llll}
0 & 0 & 546 & 0
\end{array}\right]
$$




$$
\begin{aligned}
P_{45}^{2017} & =\left[\begin{array}{cccccc}
p_{45}^{(0)} & q_{x 45}^{(0,1)} & q_{45}^{(0,2)} & q_{45}^{(0,3)} & q_{45}^{(0,4)} & q_{45}^{(0,5)} \\
0 & p_{45}^{(1)} & q_{x 45}^{(1,2)} & q_{45}^{(1,3)} & q_{45}^{(1,4)} & q_{45}^{(1,5)} \\
0 & 0 & p_{45}^{(2)} & q_{45}^{(2,3)} & q_{45}^{(2,4)} & q_{45}^{(2,5)} \\
0 & 0 & 0 & p_{45}^{(3)} & q_{45}^{(3,4)} & q_{45}^{(3,5)} \\
0 & 0 & 0 & 0 & p_{45}^{(4)} & q_{45}^{(4,5)}
\end{array}\right]_{2017} \\
& =\left[\begin{array}{cccccc}
0 & 0.98 & 0 & 0.10 & 0 & 0.01 \\
0 & 0 & 0.97 & 0.02 & 0 & 0.01 \\
0 & 0 & 0.92 & 0.05 & 0.02 & 0.01 \\
0 & 0 & 0 & 0.97 & 0.02 & 0.01 \\
0 & 0 & 0 & 0 & 0.99 & 0.01
\end{array}\right]
\end{aligned}
$$

Given the allocation of female social workers by category and the studied cohort in the following year (when they are $x+1$ years old), we can calculate:

$$
S_{46}^{2018}=S_{45}^{2017} P_{45}^{2017}=\left[S_{46}^{(0)} S_{46}^{(1)} S_{46}^{(2)} S_{46}^{(3)} S_{46}^{(4)} S_{46}^{(5)}\right]_{2018}
$$

In Table 3, we present the forecast of the availability of female social workers aged 45 in 2017 up to the studied year 2032, when they will be 60 years old. Additionally, in Table 3, we include the hypothesized improvements due to knowledge management activities implemented in social work organizations. The forecast is based on a multiple decrement model.

Table 3. Female Social Workers aged 45 in 2017 to aged 60 in 2032.

\begin{tabular}{cccccccccccccc}
\hline \multicolumn{10}{c}{ Original } \\
\hline Year & Age & SWS & SWT & FPSW & CPE & RE & DE & SWS & SWT & FPSW & CPE & RE & DE \\
\hline 2017 & 45 & 0 & 0 & 546.00 & 0 & 0 & 0 & 0 & 0 & 546.00 & 0 & 0 & 0 \\
2018 & 46 & 0 & 0 & 502.32 & 27.30 & 10.92 & 5.46 & 0 & 0 & 524.16 & 10.92 & 5.46 & 5.46 \\
2019 & 47 & 0 & 0 & 462.13 & 51.60 & 21.40 & 10.86 & 0 & 0 & 503.19 & 21.08 & 10.87 & 10.86 \\
2020 & 48 & 0 & 0 & 425.16 & 73.16 & 31.46 & 16.22 & 0 & 0 & 483.07 & 30.51 & 16.21 & 16.22 \\
2021 & 49 & 0 & 0 & 391.15 & 92.22 & 41.12 & 21.51 & 0 & 0 & 463.74 & 39.25 & 21.48 & 21.51 \\
2022 & 50 & 0 & 0 & 359.86 & 109.01 & 50.37 & 26.76 & 0 & 0 & 445.19 & 47.35 & 26.69 & 26.76 \\
2023 & 51 & 0 & 0 & 331.07 & 123.73 & 59.25 & 31.95 & 0 & 0 & 427.39 & 54.83 & 31.83 & 31.95 \\
2024 & 52 & 0 & 0 & 304.58 & 136.57 & 67.75 & 37.09 & 0 & 0 & 410.29 & 61.74 & 36.88 & 37.09 \\
2025 & 53 & 0 & 0 & 280.22 & 147.71 & 75.89 & 42.18 & 0 & 0 & 393.88 & 68.09 & 41.85 & 42.18 \\
2026 & 54 & 0 & 0 & 257.80 & 157.29 & 83.69 & 47.22 & 0 & 0 & 378.12 & 73.93 & 46.73 & 47.22 \\
2027 & 45 & 0 & 0 & 546.00 & 0 & 0 & 0 & 0 & 0 & 363.00 & 79.27 & 51.52 & 52.20 \\
2028 & 46 & 0 & 0 & 502.32 & 27.30 & 10.92 & 5.46 & 0 & 0 & 348.48 & 84.15 & 56.22 & 57.15 \\
2029 & 47 & 0 & 0 & 462.13 & 51.60 & 21.40 & 10.86 & 0 & 0 & 334.54 & 88.60 & 60.83 & 62.03 \\
2030 & 48 & 0 & 0 & 425.16 & 73.16 & 31.46 & 16.22 & 0 & 0 & 321.16 & 92.63 & 65.34 & 66.87 \\
2031 & 49 & 0 & 0 & 391.15 & 92.22 & 41.12 & 21.51 & 0 & 0 & 308.31 & 96.27 & 69.75 & 71.66 \\
2032 & 50 & 0 & 0 & 359.86 & 109.01 & 50.37 & 26.76 & 0 & 0 & 295.97 & 99.55 & 74.06 & 76.41 \\
\hline
\end{tabular}

Data source: [90], own calculations.

Table 4 provides a summary of the important hypothesized improvements due to knowledge management activities implemented in social work organizations.

Table 4. Difference in female Social Workers aged 45 in 2017 to aged 60 in 2032.

\begin{tabular}{ccccc}
\hline \multicolumn{5}{c}{ Difference } \\
\hline Year & Age & FPSW & CPE & RE \\
\hline 2017 & 45 & 0 & 0 & 0 \\
2018 & 46 & 21.84 & -16.38 & -5.46 \\
2019 & 47 & 41.06 & -30.52 & -10.53 \\
2020 & 48 & 57.91 & -42.65 & -15.25 \\
\hline
\end{tabular}


Table 4. Cont

\begin{tabular}{ccccc}
\hline \multicolumn{5}{c}{ Difference } \\
\hline Year & Age & FPSW & CPE & RE \\
\hline 2021 & 49 & 72.59 & -52.97 & -19.64 \\
2022 & 50 & 85.33 & -61.66 & -23.68 \\
2023 & 51 & 96.32 & -68.90 & -27.42 \\
2024 & 52 & 105.71 & -74.83 & -30.87 \\
2025 & 53 & 113.66 & -79.62 & -34.04 \\
2026 & 54 & 120.32 & -83.36 & -36.96 \\
2027 & 45 & 125.82 & -86.19 & -39.64 \\
2028 & 46 & 130.28 & -88.20 & -42.08 \\
2029 & 47 & 133.79 & -89.50 & -44.30 \\
2030 & 48 & 136.47 & -90.16 & -46.31 \\
2031 & 49 & 138.40 & -90.27 & -48.14 \\
2032 & 50 & 139.65 & -89.89 & -49.78 \\
\hline \multicolumn{5}{c}{ Data source: [90], own calculations. }
\end{tabular}

\section{Discussion}

Nowadays, there is an imperative to seek sustainable development in all dimensions, including the social dimension [91]. Moreover, as [92] emphasizes, in a socially sustainable society individuals do not have to tackle any structural obstacles related to many aspects of their functioning, including health and social services. In addition to this, social workers already recognize social sustainability, as it deals with individual health and wellbeing, nutrition, shelter, education and cultural needs [93]. Sustainability themes also have multiple implications for social work in general, such as social resilience to future economic and ecological shocks [94]. The extent and effectiveness of knowledge management in general indicate that knowledge management practices are less developed in social work centers in comparison to other fields and organizations, especially in the context of the private sector.

\subsection{Theoretical Implications}

The concept of knowledge management is novel and remains largely unexplored and underutilized in the public sector [27]. Furthermore, knowledge management is especially neglected as a research topic in the field of social work $[17,62,63]$. Similarly, the aspect of social sustainability has gained inadequate attention and recognition in previous studies [3,4]. In this paper we make four important theoretical contributions to this area.

Our first theoretical contribution to the literature of knowledge management research is applying and testing components of knowledge management to the public sector. In our study, we present a theoretical explanation and empirical validation of how knowledge management can positively influence the availability of skilled social workers. Previous studies suggested that knowledge management initiatives could help organizations to impact public policies through the more systematic and effective capture, dissemination, transfer and implementation of knowledge [51], and in this manner improve the quality of existing services and programs [31]. However, those studies did not explore the relationship between knowledge management and the availability of skilled social workers that we focus on in our research. Thus, our study presents a relevant contribution to the literature as we show how knowledge management can have the potential to influence the availability of skilled social workers and how this could potentially influence the ability of organizations to achieve their goals.

Our second theoretical contribution to the literature involves the knowledge-based view of the organization [72-74]. With our study we aim to draw attention to the importance of knowledge management in social work by establishing the primary components that underlie its functioning. Our research orientation is supported by social work researchers that propose a shift towards the knowledge-based view of social work organizations $[75,76]$. We aimed to conceptualize and empirically validate how knowledge and knowledge management can help social work organizations to deliver 
higher quality services. In line with the recommendations of [26], we go beyond the typical framework of knowledge management research in the public sector.

With our third theoretical contribution we devote attention to the previously neglected aspect of sustainable development, the social dimension of sustainability $[5,6]$. With our fourth theoretical contribution we respond to the need to include more methodological diversity in the scope of social work research [77]. By applying quantitative research methods to a sample of Slovenian social work organizations we add to previous research. The usage of such methods is also important to enhance the ability of social work organizations to understand and effectively respond to their existing challenges [95]. In our study, we focus on a sample of managers and employees working in Slovenian social work centers and measure their individual perceptions of different topics related to knowledge management.

\subsection{Practical Implications}

We used the results of our research to propose a number of relevant practical recommendations especially for managers and also for employees in social work organizations. Although their primary goal is not to create profit, we do believe they could still benefit from our suggestions. Social work organizations indeed have the responsibility to deliver high-quality services to their users and contribute to the wellbeing of society as a whole [55]. Individuals employed in such organizations have become increasingly more aware that like other organizations functioning in the context of the public sector they must respond to the growing complex demands of their users, while being exposed to a diminishing amount of resources available. Consequently, they are considering making internal improvements in order to maximize their available resources [96]. We believe, that our model provides clear reasoning for how improvements related to knowledge management activities could benefit the social work field.

We argue that there is a potential of knowledge management in influencing public policies [30] by advancing informed debate and decision making [97]. Moreover, it can impact the sustainable development of social work by enhancing the wellbeing of service users by improving the quality of services and programs [30,31]. Typically, bureaucratic organizations can exploit knowledge management advantages by empowering employees that are able to create knowledge networks and more efficiently organize their work in teams [98]. People employed in social work tend to have both communication competencies and team work skills that are both helpful in successful knowledge management initiatives. In addition, knowledge management could help ensure the appropriate number of skilled social workers in social work organizations by motivating social workers [59], enhancing their job satisfaction levels [58] and reducing their turnover intention [60].

Moreover, based on the results of our study, which indicate that knowledge management is underdeveloped in social work centers, we propose improvements in at least four areas that were examined to determine the current levels of knowledge management. Managers who are directly responsible for knowledge management in an organization can enhance the possibility of achieving the desired goals of improved wellbeing of service users, through knowledge management [99]. Therefore, social work centers could reconsider the possibility of a manager that is at least part-time responsible for all knowledge management related activities in an organization as in the majority of cases such a manager is nowadays absent. Management support is fundamental to the success of knowledge management initiatives [100]. We particularly advise managers to actively support and engage in creating and maintaining a supportive workplace environment where employees are motivated to apply and implement knowledge in their work [101]. A clearly defined incentive structure [62,102] typically encourages employees to participate in knowledge management activities. Therefore, social work centers could change their human resource management practices towards more knowledge-based compensation. Such a practice would encourage employees to engage in knowledge-intensive activities through incentive systems that recognize their involvement in knowledge processes. Organizations could potentially function better if they base their incentive system on such knowledge activities [103]. Moreover, such an incentive system could make the profession more desirable for potential students. 
As our population is ageing, it is also extremely important to engage more young people to choose the social work profession and enter the educational process. Similarly, important to the success of knowledge management is clear and active communication of expectations and benefits related to knowledge management [62]. Therefore, we would encourage delivering strong messages from management [104]. The mere existence of ideas and knowledge is not enough to improve the functioning of social work centers. Consequently, social work centers should strive to continuously critically evaluate new ideas $[105,106]$, apply new knowledge in practice $[107,108]$ and be aware that the sole existence of knowledge is not enough [12,109]. Information communication technologies directly support knowledge management practices [110]. It would be beneficial for Slovenian social work centers to solve the ongoing challenges regarding information communication technologies $[103,111]$ that are changing their existing working patterns.

Furthermore, we propose improvements in all four topics wherein we aimed to gain insight about the existing effectiveness of knowledge management. As mentioned, informed [97] and improved [112,113] decision making is a prerequisite of influencing public policies. Social work managers should provide guidelines for their subordinates on how to question existing knowledge patterns, how to creatively think about innovative solutions and analyze their applicability and how to utilize this new knowledge in organizational decision-making processes. Also mentioned above, organizing work in teams could prove to be more efficient in practice [98]. Therefore, we encourage social work centers to promote the importance and positive effect of team work to their employees [114]. On the basis of existing literature, we argue that readily available knowledge makes employees more aware of who knows what in their organization [115-117]. We encourage organizations to enhance their efforts in making knowledge readily available to every single employee. Utilizing new knowledge, additional skills and experience can positively influence the functioning of social work centers $[118,119]$. Therefore, it would be beneficial for organizations to encourage managers and employees to continuously acquire new knowledge, additional skills and experience and focus on constantly improving learning at the individual, group and organizational level [120]. The end goal of knowledge management activities should be to help social work centers achieve excellence in their daily routines $[17,121]$. We argue that they should engage and provide support for any activity or initiative that can potentially improve the quality of their overall performance [92,112], measured by the wellbeing of social services users. To conclude, we believe it is the responsibility of managers to consider which aspects of knowledge management are most effective in practice, and what role these practices might have on stimulating higher levels of organizational performance.

Considering that the case study of Slovenian female social workers actually shows that the existing patterns of entrance and exit of social workers will decrease the availability of social workers despite the increasing need for staffing, it is of paramount importance to endorse efforts that acknowledge the importance of understanding workforce entrance and exit in the social work profession on a national level in order to provide the required number of well-trained social workers who will provide wellbeing for a growing number of service users in an ageing society. Efforts to maintain or improve the availability of social workers should focus also on the quality of knowledge management activities, as this can contribute towards maintaining fully productive social workers and mitigate any intention among them to change their profession or retire early. Knowledge management measures are typically related to the four already established knowledge management process stages, namely knowledge creation, knowledge storage and retrieval, knowledge transfer and knowledge implementation $[11,12]$ and management support. They would result in improvements in use of the societal resources available to social workers through the so-called soft measures such as enhanced collaboration, enhanced communication, enhanced learning, and indirectly in enhanced performance [21]. As is evident from Table 4, we argue that in the event of successful knowledge management implementation, more female social workers would remain fully productive for a longer period, and they would be less motivated to change their profession due to various reasons, while also staying longer as active participants on the labor market. 


\subsection{Limitations and Future Research Directions}

Despite newly gained insight into knowledge management in the context of social work organizations, our paper is not without limitations. The first limitation is related to our sample frame. Due to the implementation of the GDPR act, our scope for respondents was limited. The second limitation relates to generalizability. We cannot confirm our findings across the whole field of social work, as we included only a proportion of managers and employees employed in social work centers. Third, the transition matrix is only hypothesized based on moderate estimates of how knowledge management would potentially influence the patterns of entrance and exit from the workforce of social workers.

Future research should aim to include more social work organizations, with the aim to draw final conclusions related to the field. It would also be extremely beneficial to compare our results to other European countries. Moreover, our results show that public data regarding workforce entrance and exit in general, and specifically for social workers, should be maintained and regularly published, to afford researchers better access to data regarding workforce availability. As the whole topic of knowledge management is novel and unexplored in social work, it offers several potential opportunities for future exploration for both researchers and practitioners in social work. We would especially urge follow-up studies face-to-face open-ended interviews to gain additional understanding about specific topics that are related to the extent and effectiveness of knowledge management in social work. Such methods would enable researchers to overcome issues related to interpreting the results of questionnaires that only use Likert scale ranges.

\section{Conclusions}

Our results are highly relevant and discuss the important potential impact of knowledge management on the social work profession due to the fact that: (1) there is an imperative to focus on the social dimension of sustainability as it is integral to the quality of a human system, (2) the existing supply of social workers is not sufficient to provide wellbeing for the growing elderly population, (3) at the moment, involvement in knowledge management activities in social work is not extensive enough to positively influence the functioning of social work organizations that are and will be responsible for taking care of our ageing population. Along with the sustainable development of social work, this represents the possible future path towards satisfying the ever-growing demand for social services. (4) The model we have developed allows better understanding of patterns in the social work profession regarding workforce entrance and exit and can be utilized by: (1) social work organizations that employ social workers, to increase their understanding regarding the social workers' demographics and the potential impact of knowledge management on policies and other improvements; (2) social workers' unions, i.e., with regard to negotiating processes that deal with the existing shortage of social workers; as well as (3) policy and decision makers, when discussing and developing future policies covering this important topic of our ageing society. In the long term, the results of our study regarding knowledge management can make an important contribution in providing support to ensure appropriate social services to our ageing society. Therefore, our contribution is also indirectly towards the sustainability of our society as a whole. To conclude, we believe that while addressing the challenge of ensuring the wellbeing of service users it is also important to acknowledge the institutional framework, as it can potentially act as a major constraint. A thorough reflection on the existing legislation and the way services are currently being provided is necessary. We believe that knowledge management could contribute to improving the existing state of affairs to some degree, however, it cannot yet move social work beyond the challenges related to its institutional framework.

Author Contributions: The contributions of authors are as follows: conceptualization: S.C., V.D. and D.B., abstract: S.C., V.D. and D.B., introduction: S.C., V.D. and D.B., materials and methods: S.C., V.D. and D.B., results: S.C., V.D. and D.B., discussion: S.C., V.D. and D.B., conclusions: S.C., V.D. and D.B. and references: S.C.

Funding: The authors acknowledge that the paper Knowledge Management and the Sustainable Development of Social Work, was financially supported by the Slovenian Research Agency, Program P5-0364-The Impact of 
Corporate Governance, Organizational Learning, and Knowledge Management on Modern Organization and by the Slovenian Research Agency, Program J6-9396-Development of Social Infrastructure and Services for Community Based Long-Term Care.

Acknowledgments: We would like to express our deep gratitude to the Social Chamber of Slovenia and its secretary general Vilko Kolbl for their help in acquiring data from our respondents. Additionally, we would also like to thank all of our respondents that filled out our questionnaire related to the topic of knowledge management in Slovenian social work centers and for their consent to participate in this research.

Conflicts of Interest: The authors declare no conflict of interest.

\section{References}

1. Social Life: Social Sustainability Definition. Available online: http://www.social-life.co/ (accessed on 23 September 2019).

2. Woodcraft, S.; Bacon, N.; Caistor-Arendar, L.; Hackett, T. Design for Social Sustainability: A Framework for Creating Thriving New Communities; Social Life: London, UK, 2012.

3. Ajmal, M.M.; Khan, M.; Hussain, M.; Helo, P. Conceptualizing and incorporating social sustainability in the business world. Int. J. Sustain. Dev. World Ecol. 2018, 25, 327-339. [CrossRef]

4. Staniškiene, E.; Stankevičiute, Ž. Social sustainability measurement framework: The case of employee perspective in CSR-committed organization. J. Clean. Prod. 2018, 188, 708-719. [CrossRef]

5. Cuthill, M. Strengthening the "social" in sustainable development: Developing a conceptual framework for social sustainability in a rapid urban growth region in Australia. Sustain. Dev. 2010, 18, 362-373. [CrossRef]

6. Vavik, T.; Keitsch, M.M. Exploring relationships between universal design and social sustainable development: Some methodological aspects of the debate on the sciences of sustainability. Sustain. Dev. 2010, 18, $295-305$. [CrossRef]

7. Bostrom, M. A missing pillar? Challenges in theorizing and practicing social sustainability: Introduction to the special issue. Sustain. Sci. Pract. Pol. 2012, 8, 3-14. [CrossRef]

8. De Vries, M.; Nemec, J. Public Sector Reform: An Overview of Recent Literature and Research on NPM and Alternative Paths. Int. J. Public Sect. Manag. 2013, 26, 4-16. [CrossRef]

9. Jashapara, A. Knowledge Management: An Integrated Approach; Pearson Education: London, UK, 2011.

10. Dalkir, K. Knowledge Management in Theory and Practice; Elsevier Butterworth-Heinemann: Burlington, NJ, USA, 2005.

11. Hicks, R.; Dattero, R.; Galup, S. The five-tier knowledge management hierarchy. J. Knowl. Manag. 2006, 10, 19-31. [CrossRef]

12. Alavi, M.; Leidner, D.E. Review: Knowledge management and knowledge management systems: Conceptual foundations and research issues. MIS Q. 2001, 25, 107-136. [CrossRef]

13. Ward, V.; Smith, S.; Keen, J.; West, R.; House, A. Creating and implementing local health and wellbeing policy: Networks, interactions and collective knowledge creation amongst public sector managers. Evid. Policy 2018, 14, 477-498. [CrossRef]

14. Heisig, P. Harmonisation of knowledge management-Comparing $160 \mathrm{KM}$ frameworks around the globe. J. Knowl. Manag. 2009, 13, 4-31. [CrossRef]

15. Dawson, R. Knowledge capabilities as the focus of organizational development and strategy. J. Knowl. Manag. 2001, 4, 320-327. [CrossRef]

16. Kogut, B.; Zander, U. What firms do? Coordination, identity and learning. Organ. Sci. 1996, 7, 502-518. [CrossRef]

17. Downes, T.V. An Evaluation of Knowledge Management Practices in Nonprofit Community Services Organizations in Australia. Ph.D. Thesis, Southern Cross University, Lismore, Australia, 2014.

18. Lin, H.F. Antecedents of the stage-based knowledge management evolution. J. Knowl. Manag. 2011, 15, 136-155. [CrossRef]

19. Azmee, N.N.; Kassim, N.A.; Abdullah, C.Z.H. Dimensions of Knowledge Management Maturity: Top Management Support and Leadership, People, and Information Technology. J. Inf. Knowl. Manag. 2017, 7, 1-7.

20. Bharadway, S.S.; Chauhan, S.; Raman, A. Impact of Knowledge Management Capabilities on Knowledge Management Effectiveness in Indian Organizations. J. Decis. Mak. 2015, 40, 421-434. [CrossRef] 
21. Anantatmula, V.S. Linking KM effectiveness attributes to organizational performance. VINE 2007, 37, 133-149. [CrossRef]

22. Kim, Y.W.; Ko, J. HR practices and knowledge sharing behavior: Focusing on the moderating effect of trust in supervisor. Public Pers. Manag. 2014, 43, 586-607. [CrossRef]

23. Mariano, S.; Awazu, Y. Artifacts in knowledge management research: A systematic literature review and future research directions. J. Knowl. Manag. 2016, 20, 1333-1352. [CrossRef]

24. Centobelli, P.; Cerchione, R.; Esposito, E. How to deal with knowledge management misalignment: A taxonomy based on a 3D fuzzy methodology. J. Knowl. Manag. 2018, 22, 538-566. [CrossRef]

25. Centobelli, P.; Cerchione, R.; Esposito, E. Efficiency and effectiveness of knowledge management systems in SMEs. Prod. Plan. Control 2019, 30, 779-791. [CrossRef]

26. Massaro, M.; Dumay, J.; Garlatti, A. Public sector knowledge management: A structured literature review. J. Knowl. Manag. 2015, 19, 530-558. [CrossRef]

27. Špaček, D. Knowledge management in public administration-What can be found in research outputs in the Czech Republic-Preliminary findings. In Proceedings of the 20th International Conference on Current Trends in Public Sector Research, Brno, Czech Republic, 21-22 January 2016.

28. Arora, E. Knowledge Management in Public Sector. J. Arts Sci. Commer. 2011, 2, 165-171.

29. Wiig, K. Knowledge management in public administration. J. Knowl. Manag. 2002, 6, 224-239. [CrossRef]

30. Hardina, D. Ten characteristics of empowerment-oriented social service organizations. Adm. Soc. Work 2005, 29, 23-42. [CrossRef]

31. Ukil, M.I. The impact of Employee Empowerment on Employee Satisfaction and Service Quality: Empirical Evidence from Financial Enteprizes in Bangladesh. Business 2016, 17, 178-189. [CrossRef]

32. Oluikpe, P. Developing a corporate knowledge management strategy. J. Knowl. Manag. 2012, 16, 862-878. [CrossRef]

33. Ringel-Bickelmaier, C.; Ringel, M. Knowledge management in international organisations. J. Knowl. Manag. 2010, 14, 524-539. [CrossRef]

34. Cong, X.; Pandya, K.V. Issues of knowledge management in the public sector. Electron. J. Knowl. Manag. 2003, 1, 25-33.

35. Willem, A.; Buelens, M. Knowledge sharing in public sector organizations: The effect of organizational characteristics on interdepartmental knowledge sharing. J. Public Adm. Res. Theory 2007, 17, 581-606. [CrossRef]

36. Leung, Z.C.S. Knowledge Management in Social Work: Towards a Conceptual Framework. J. Technol. Hum. Serv. 2007, 25, 181-198. [CrossRef]

37. McCoyd, J.L.M.; Johnson, Y.M.; Munch, S.; LaSala, M. Quantocentric culture: Ramifications for social work education. Soc. Work Educ. 2009, 28, 811-827. [CrossRef]

38. Broadhurst, K.; Hall, C.; White, S.; Pithouse, A. Risk, instrumentalism and the humane project in social work: Identifying the informal logics of risk management in children's statutory services. Br. J. Soc. Work 2010, 40, 352-370. [CrossRef]

39. Al Ahbabi, S.; Singh, S.K.; Balasubramian, S.; Singh Gaur, S. Employee perception of impact of knowledge management processes on public sector performance. J. Knowl. Manag. 2019, 23, 351-373. [CrossRef]

40. Hartnett, H.P.; Tabone, J.K.; Orlsene, L. Aging at Work: The Importance of Understanding Accommodation in Social Work Practice. J. Sociol. Soc. Work 2019, 7, 36-43. [CrossRef]

41. Hall, N. Social work through an indigenous lens: Reflections on the state of our profession. In Social Work: Making a World of Difference: Social Work Around the World IV in the Year of IFSW's 50th Jubilee; IFSW: Berne, Switzerland; FAFO: Oslo, Norway, 2006.

42. Kuzmanič Korva, D.; Perkovič, M.; Kovač, J.; Rapošta-Tajnšek, P.; Flaker, V. Preoblikovanje Organiziranosti Centrov za Socialno Delo v Republiki Sloveniji; Skupnost CSD Slovenije: Ljubljana, Slovenia, 2004.

43. Ministry of Labour, Family, Social Affairs and Equal Opportunities. Available online: http://www.mddsz. gov.si/197/delovna_podrocja/sociala/reorganizacija_centrov_za_socialno_delo/ (accessed on 5 April 2019).

44. Harlow, E. Why don't women want to be social workers anymore? New managerialism, postfeminism and the shortage of social workers in social services departments in England and Wales. Eur. J. Soc. Work 2004, 7, 167-179. [CrossRef]

45. Squires, A.; Jylha, V.; Jun, J.; Ensio, A.; Kinnune, J. A scoping review of nursing workforce planning and forecasting research. J. Nurs. Manag. 2017, 25, 587-596. [CrossRef] 
46. European Commission. The 2018 Ageing Report; European Commission: Luxemburg, 2017.

47. Dimovski, V.; Grah, B.; Colnar, S. Modelling the industrial workforce dynamics and exit in the ageing society. In Proceedings of the 9th IFAC Conference on Manufacturing Modelling, Management and Control, Berlin, Germany, 28-30 August 2019.

48. United Nations, World Population Prospects: The 2015 Revision. Available online: http://esa.un.org/unpd/ wpp/ (accessed on 5 July 2019).

49. Eurostat, Eurostat Database: Demographic Balances and Selected Indicators, EUROPOP 2018, Slovenia. Available online: https://www.stat.si/StatWeb/en/news/Index/8316 (accessed on 8 September 2019).

50. Marc, M.; Bartosiewicz, A.; Burzynska, J.; Chmiel, Z.; Januszewicz, P. A nursing shortage-a prospect of global and local policies. Int. Counc. Nurs. 2019, 66, 9-16. [CrossRef]

51. Riege, A.; Lindsay, N. Knowledge management in the public sector: Stakeholder partnership in the public policy development. J. Knowl. Manag. 2006, 10, 24-39. [CrossRef]

52. Ortenblad, A. Who is the learning organization for? A stakeholder contingency approach to contextualizing managerial panaceas. In Handbook of Research on Knowledge Management: Adaptation and Context; Ortenblad, A., Ed.; Edward Elgar: Cheltenham, UK; Northampton, MA, USA, 2014.

53. Ortenblad, A.; Koris, R. Is the learning organization idea relevant to higher educational institutions? A literature review and a multi-stakeholder contingency approach. Int. J. Educ. Manag. 2014, 28, 173-214. [CrossRef]

54. Beddoe, L. Investing in the future: Social workers talk about research. Br. J. Soc. Work 2011, 41, 557-575. [CrossRef]

55. Bloice, L.; Burnett, S. Barriers to knowledge sharing in third sector social care: A case study. J. Knowl. Manag. 2016, 20, 125-145. [CrossRef]

56. Institute for Research and Innovation in Social Services. Available online: https://lx.iriss.org.uk/sites/default/ files/resources/sharing_knowledge_improving_practice_changing_lives.pdf (accessed on 29 October 2019).

57. Lettieri, E.; Borga, F.; Savoldelli, A. Knowledge management in non-profit organizations. J. Knowl. Manag. 2004, 8, 16-30. [CrossRef]

58. Kianto, A.; Vanhala, M.; Hielmann, P. The impact of knowledge management on job satisfaction. J. Knowl. Manag. 2016, 20, 621-636. [CrossRef]

59. North, K.; Hornung, T. The Benefits of Knowledge Management-Results of the German Award "Knowledge Manager 2002". J. Univers. Comput. Sci. 2002, 9, 361-389.

60. Muchinsky, P.M.; Tuttle, M.L. Employee turnover: An empirical and methodological assessment. J. Vocat. Behav. 1979, 14, 43-77. [CrossRef]

61. Alexanderson, K. Vilja, Kunna, Förstå: Om Implementering av Systematisk Dokumentation för Verksamhetsutveckling i Socialtjänsten [Willingness, Comprehension, Capability: About Implementation of Systematic Documentation for Developing Social Work in the Public Social Work Services]. Ph.D. Thesis, Orebro University Library, Orebro, Sweden, 2006.

62. Austin, M.J.; Ciaassen, J.; Vu, C.M.; Mizrahi, P. Knowledge Management: Implications for Human Service Organizations. J. Evid. Based Soc. Work 2008, 5, 361-389. [CrossRef]

63. Leung, Z.C.S. Knowledge management in social work-The interplay of knowledge sharing platforms. Int. Soc. Work 2014, 57, 143-155. [CrossRef]

64. Social Protection Institute of the Republic of Slovenia. Available online: https://www.irssv.si/upload2/ Socialni\%20polozaj\%20v\%20Sloveniji\%202015_2016_dopolnjeno\%20koncno\%20porocilo_2.pdf (accessed on 28 October 2019).

65. Bjorkenheim, J. Knowledge and social work in health care: The case of Finland. Soc. Work Health Care 2007, 44, 261-278. [CrossRef]

66. Ministry of Public Administration. Available online: http://www.mju.gov.si/si/delovna_podrocja/razvoj_ projektov_kakovost_javne_uprave_in_kohezijska_politika/strategija_razvoja_javne_uprave/ (accessed on 29 October 2019).

67. Bogataj, D.; McDonnell, D.R.; Bogataj, M. Management, financing and taxation of housing stock in the shrinking cities of aging societies. Int. J. Prod. Econ. 2016, 181, 2-13. [CrossRef]

68. Bogataj, D.; McDonnell, D.; Bogataj, M. Reverse mortgage schemes financing urban dynamics using the multiple decrement approach. Springer Proc. Math. Stat. 2015, 135, 27-47. [CrossRef] 
69. Rogelj, V.; Bogataj, D. Planning and financing the home and facility-based care using the multiple decrement approach. J. Decis. Syst. 2018, 27, 132-143. [CrossRef]

70. Kahn, W.A. Caring for the caregivers: Patterns of organizational caregiving. Adm. Sci. Q. 1993, 38, 539-563. [CrossRef]

71. Henttonen, K.; Kianto, A.; Ritala, P. Knowledge sharing and individual work performance: An empirical study of a public sector organization. J. Knowl. Manag. 2016, 20, 749-768. [CrossRef]

72. Grant, R. Towards a Knowledge Based Theory of the Firm. Strateg. Manag. J. 1996, 17, 109-122. [CrossRef]

73. Hislop, D.; Bosua, R.; Helms, R. Knowledge Management in Organizations—A Critical Introduction, 4th ed.; Oxford University Press: Oxford, MS, USA, 2018.

74. Kogut, B.; Zander, U. Knowledge of the firm and the evolutionary theory of the multinational corporation. J. Int. Bus. Stud. 2003, 34, 516-529. [CrossRef]

75. Edge, K. Powerful public sector knowledge management: A school district example. J. Knowl. Manag. 2005, 9, 42-52. [CrossRef]

76. Fitch, D. Examination of the child protective services decision-making context with implications for decision support system design. J. Soc. Serv. Res. 2006, 32, 117-134. [CrossRef]

77. Soydan, H. Producing Knowledge for Evidence-Based Practice and the Future of Social Work Research. In Evidence Based and Knowledge Based Social Work: Research Methods and Approaches in Social Work Research; Aarhus University Press: Aarhus, Denmark, 2008.

78. Podsakoff, P.M.; MacKenzie, S.B.; Lee, J.Y.; Podsakoff, N.P. Common method biases in behavioral research: A critical review of the literature and recommended remedies. J. Appl. Psychol. 2003, 88, 879-903. [CrossRef]

79. Podsakoff, P.M.; MacKenzie, S.B.; Podsakoff, N.P. Sources of method bias in social science research and recommendations on how to control it. Annu. Rev. Psychol. 2012, 63, 539-569. [CrossRef]

80. McPhail, B.A. Setting the Record Straight: Social Work is Not a Female-Dominated Profession. Soc. Work 2004, 49, 323-326. [CrossRef]

81. Hoem, J.M. Point estimation of forces of transition in demographic models. J. R. Stat. Soc. 1970, 33, $275-289$. [CrossRef]

82. Nurminen, M.; Nurminen, T. Multistate worklife expectancies. Scand. J. Work Environ. Health 2005, 31, 169-178. [CrossRef] [PubMed]

83. Dudel, C.; Lopez Gomez, M.A.; Benavides, F.G.; Myrskylä, M. The length of working life in Spain: Levels, recent trends, and the impact of the financial crisis. Eur. J. Popul. 2018, 34, 769-791. [CrossRef] [PubMed]

84. Dudel, C.; Myrskylä, M. Working Life Expectancy at Age 50 in the United States and the Impact of the Great Recession. Demography 2017, 54, 2101-2123. [CrossRef] [PubMed]

85. Pedersen, J.; Bjorner, J.B. Worklife expectancy in a cohort of Danish employees aged 55-65 years-Comparing a multi-state Cox proportional hazard approach with conventional multi-state life tables. BMC Public Health 2017, 17, 879. [CrossRef] [PubMed]

86. Schoen, R. Multistate Transfer Rate Estimation from Adjacent Populations. Popul. Res. Policy Rev. 2016, 35, 217-240. [CrossRef]

87. Nurminen, M. Worklife expectancies of fixed-term Finnish employees in 1997-2006. Scand. J. Work Environ. Health 2008, 34, 83-95. [CrossRef]

88. Deshmukh, S. Multiple Decrement Models in Insurance: An Introduction Using R; Springer: New Delhi, India, 2012.

89. Promislow, S.D. Fundamentals of Actuarial Mathematics, 3rd ed.; John Wiley \& Sons: Chichester, UK, 2015.

90. Slovenian Statistical Office. Delovno Aktivno Prebivalstvo Po Spol, Skd Dejavnost, Leto, Starostni Razred. Available online: https://pxweb.stat.si/pxweb/Dialog/SaveShow.asp (accessed on 15 July 2019).

91. Belchior Rocha, H. Social Work Practices and the Ecological Sustainability of Socially Vulnerable Communities. Sustainability 2018, 10, 1312. [CrossRef]

92. Missimer, M.; Robert, K.H.; Broman, G. A strategic approach to social sustainability-Part 2: A principle-based definition. J. Clean. Prod. 2017, 140, 42-52. [CrossRef]

93. Brennan, E. Definitions for social sustainability and social work paper. In White Paper Distributed for CSWE Conference; Portland State University: Portland, OR, USA, 2010.

94. Blake, J. Sustainable communities and social work practice learning: Reflections on emergent, learning partnerships. J. Pract. Teach. Learn. 2009, 9, 93-114. [CrossRef] 
95. Teater, B.; Devaney, J.; Forrester, D.; Scourfield, J.; Carpenter, J. Quantitative Research Methods for Social Work: Making Social Work Count, 1st ed.; Palgrave: London, UK, 2016.

96. Dimovski, V.; Penger, S.; Peterlin, J.; Grah, B.; Černe, M.; Klepec, M. Advanced Management and Leadership Practice; Pearson Education Limited: Essex, UK, 2017.

97. Myers, P.S. A Normative Model of Knowledge Management Effectiveness. In Handbook of Research on Knowledge Management: Adaptation and Context; Ortenblad, A., Ed.; Edward Elgar Publishing: Cheltenham, UK; Northampton, MA, USA, 2014; pp. 28-52.

98. Nishikawa, M. (Re)defining care workers as knowledge workers. Gend. Work Organ. 2011, 18, $113-135$. [CrossRef]

99. Dehgani, R.; Ramsin, R. Methodologies for developing knowledge management systems: An evaluation framework. J. Knowl. Manag. 2015, 19, 682-710. [CrossRef]

100. Garrido-Moreno, A.; Lockett, N.; Garcia-Morales, V. Paving the way for CRM success: The mediating role of knowledge management and organizational commitment. Inf. Manag. 2014, 51, 1031-1042. [CrossRef]

101. Akbari, N.; Ghaffari, A. Verifying relationship of knowledge management initiatives and the empowerment of human resources. J. Knowl. Manag. 2017, 21, 1120-1141. [CrossRef]

102. Bosilj Vukšić, V.; Pejić Bach, M.; Garrido-Moreno, A.; Lockett, N.; Garcia-Morales, V. Exploring the role of knowledge management practices in fostering customer relationship management as a catalyst of marketing innovation. Balt. J. Manag. 2015, 10, 393-412. [CrossRef]

103. Tapio Inkinen, H.; Kianto, A.; Vanhala, M. Knowledge management practice and innovation performance in Finland. Balt. J. Manag. 2015, 10, 432-435. [CrossRef]

104. Cabrera, A.; Collins, W.C.; Salgado, J.F. Determinants of individual engagement in knowledge sharing. Int. J. Hum. Resour. Manag. 2006, 17, 245-264. [CrossRef]

105. Bontis, N. Information Bombardment: Rising Above the Digital Onslaught; Institute for Intellectual Capital Research: Hamilton, ON, Canada, 2011.

106. Karamitri, I.; Talias, M.A.; Bellali, T. Knowledge Management practices in healthcare settings: A systematic review. Int. J. Health Plan. Manag. 2015, 32, 4-18. [CrossRef]

107. Bierly, P.E.; Damanpour, F.; Santoro, M.D. The application of external knowledge: Organizational conditions for exploration and exploitation. J. Manag. Stud. 2009, 46, 481-509. [CrossRef]

108. Choi, S.Y.; Lee, H.; Yoo, Y. The impact of information technology and transactive memory systems on knowledge sharing, application and team performance. MIS Q. 2010, 34, 855-870. [CrossRef]

109. Penrose, E.T. The Theory of the Growth of the Firm, 4th ed.; Oxford University Press: Oxford, MS, USA, 2009.

110. Andreeva, T.; Kianto, A. Does knowledge management really matter? Linking knowledge management practices, competitiveness and economic performance. J. Knowl. Manag. 2012, 617-636. [CrossRef]

111. Ouriques, R.A.B.; Wnuk, K.; Gorschek, T.; Berntsson Svensson, R. Knowledge Management Strategies and Processes in Agile Software Development: A Systematic Literature Review. Int. J. Softw. Eng. Knowl. Eng. 2018, 29, 345-380. [CrossRef]

112. King, W.R. Knowledge Management and Organizational Learning; Springer: Boston, MA, USA, 2009.

113. Carneiro, A. How does knowledge management influence innovation and competitiveness? J. Knowl. Manag. 2000, 4, 87-98. [CrossRef]

114. Eppler, M.; Sukowski, O. Managing Team Knowledge: Core Processes, Tools and Enabling Factors. Eur. Manag. J. 2000, 18, 334-341. [CrossRef]

115. Rodrigues, A.; Azevedo, C.; Calvo, V. Internal communication in organizations: Practical instruments to help the shift change. J. Educ. Technol. Health 2016, 2, 1-10. [CrossRef]

116. Alavi, M.; Leidner, D. Knowledge Management Systems: Issues, Challenges, and Benefits. Commun. Assoc. Inf. Syst. 1999, 1, 1-27. [CrossRef]

117. Argote, L. Organizational learning research: Past, present and future. Manag. Learn. 2011, 42, $439-446$. [CrossRef]

118. Senge, P.M. The Fifth Discipline: The Art \& Practice of a Learning Organization; Doubleday: New York, NY, USA, 1990.

119. Resatsch, F.; Faisst, U. Measuring the performance of knowledge management initiatives. In Proceedings of the Fifth European Conference on Organizational knowledge, learning and Capabilities, Innsbruck, Austria, 2-3 April 2004. 
120. Westerlund, M.; Rajala, R. Learning and innovation in inter-organizational network collaboration. J. Bus. Ind. Mark. 2010, 25, 435-442. [CrossRef]

121. Anantatmula, V.S.; Stankosky, M. KM criteria for different types of organisations. Int. J. Knowl. Learn. 2008, 4, 18-35. [CrossRef]

(C) 2019 by the authors. Licensee MDPI, Basel, Switzerland. This article is an open access article distributed under the terms and conditions of the Creative Commons Attribution (CC BY) license (http://creativecommons.org/licenses/by/4.0/). 